\title{
Seismic activity in Ghana: past, present and future
}

\author{
Paulina Ekua Amponsah \\ Geological Survey Department, Accra, Ghana
}

\begin{abstract}
Though Ghana is far away from the major earthquake zones of the world, it is prone to earthquake disaster. Ghana has records of damaging earthquakes dating as far back as 1615. The last three major events occurred in 1862, 1906 and 1939. This paper presents the main historical and current instrumental recorded earthquakes of Ghana and the steps being taken to mitigate the negative effects of such disastrous occurrences in the country. The discussion is based on historical and current data obtained from the seismological observatories in Accra and Kukurantumi. Historical earthquakes of magnitude greater than 6.0 and current local tremors with magnitudes ranging from 1.0 to 4.8 on the Richter scale have been recorded since the establishment of the seismograph stations.
\end{abstract}

Key words Ghana-seismicity

\section{Introduction}

Ghana is located on the southeastern margin of the West Africa craton and is far away from the major earthquake zones that mark the present day lithospheric plate boundaries. However, a number of major and minor earthquakes have struck the country in past and present. Earth tremors of magnitude ranging from 1.0 to 4.8 on the Richter scale have been recorded in recent times (fig. 1).

Instrumental recording of earthquakes in Ghana began in 1914 when the colonial government installed a Milne's single-boom seismograph in the country. It operated until 1933 when it ceased recording (Banson, 1970) due to financial constraints. Several minor shocks were recorded during the period when the seis-

Mailing Address: Dr. Paulina Ekua Amponsah, Geological Survey Department, P.O. Box M. 80, Accra, Ghana; e-mail:pekua2@hotmail.com mograph was in operation. In March 1973, a seismograph observatory equipped with a WorldWide Standard Seismograph Network (WWSSN) system was established at Kukurantumi in Eastern Ghana. It operated continuously until October 1974 and then intermittently until continuous recording began again in 1977 (Quaah, 1980). At present, there is a nine-station radio telemetric network with a central recording station at the Head Office of the Geological Survey Department in Accra. It is an analog recording system. Plans are underway to procure a digital recording system. Heat pens (Hot-Stylus) are used for the recordings (Amponsah, 2002).

\section{Geological setting and previous studies}

About two thirds of the land surface of Ghana is covered by Birimian rocks that are of paleoproterozoic age. These rocks form the easternmost component of the Man Shield of West African craton that has remained stable since $1.7 \mathrm{Ga}$. The eastern portion of the country is predominantly underlain by middle to late 


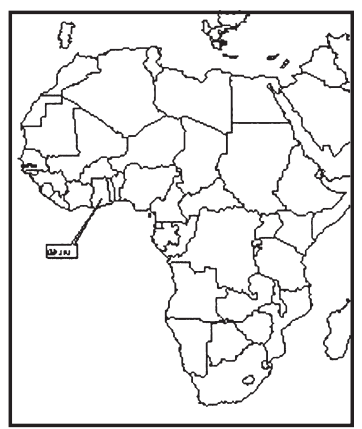

LEGEND

Scale of magnitude

- Less than or equal to 2.4

$\triangle \quad$ Between 2.5 and 4.0

$\triangle \quad$ Greater than or equal to 4.1

- Fault

$\square$ Seismograph station

$\triangle \quad$ Historical events

- Settlement

Geology

Red continental de posit mainly limonitic sand.

Quartzite, phyllite, grit, conglomerate

Quartzite, shale, phyllite

Acidic and basic gneiss schist and migmatities

Metamorphosed lava and pyrodastic rock

Pre

Uill Sandstone Grits and shales

WIIS Sandstone Grits

Mainly Sandstone

Basaltic. Andesitic and Trachytic

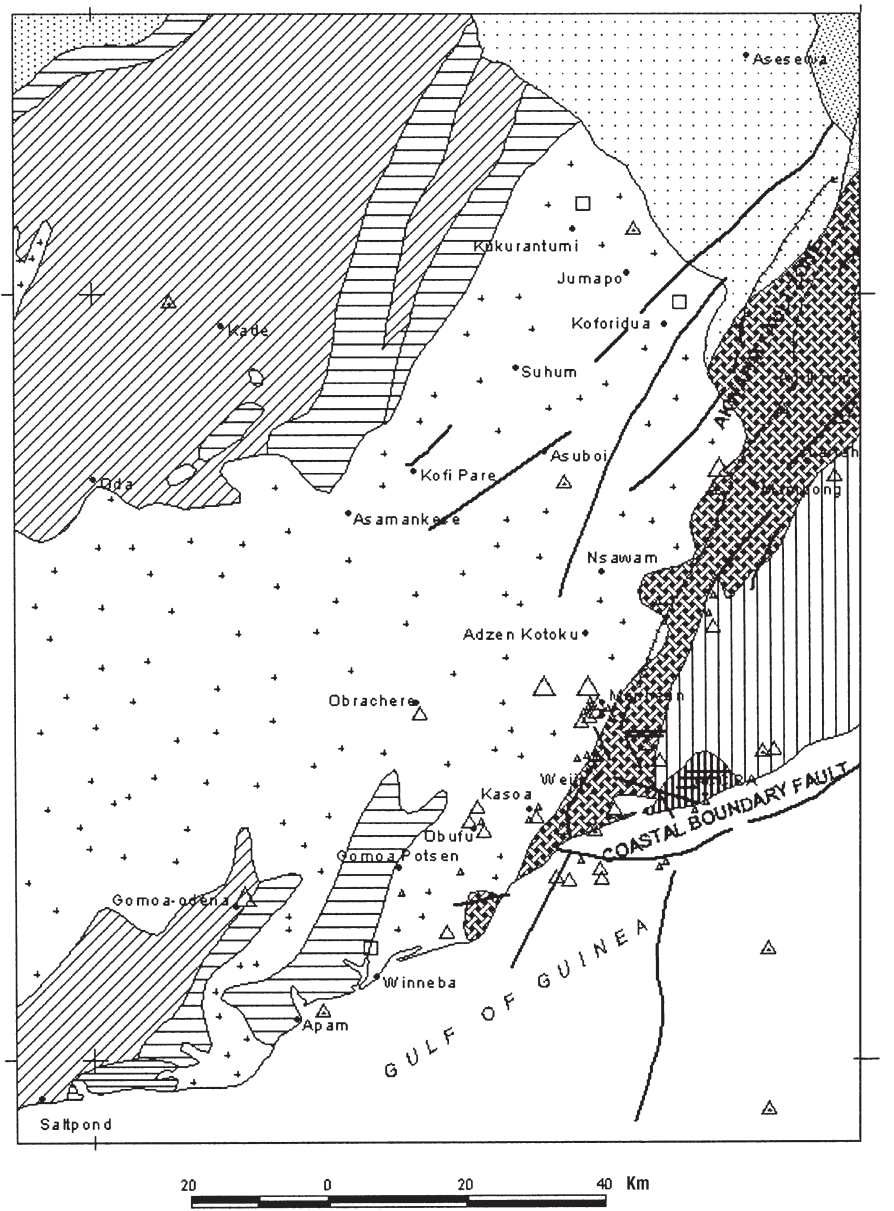

Fig. 1. Seismicity of southeastern Ghana.

Proterozoic rock units that are differently named as Dahomeyan, Togo, Buem and Voltain belts (Leube, et al., 1990).

Work done by Bacon and Quaah (1981) indicates that most of the earthquakes in Ghana occur in the western part of Accra at the junction of the two major fault systems namely, the Coastal boundary fault and Akwapim fault zone. According to them most of the epicentres are located south of Weija suggesting that there is little activity north-eastward along the Akwapim range and westward along the Coastal boundary fault. It is evident from their results that there is a low level of seismic activity scattered along the Akwapim fault zone that could be due to normal faulting suggested by Burke (1969). In Quaah and Bacon's view, the epicentres of the located earthquakes are related to the level of activity of the faults. This they allege to be due to the existence of an old thrust zone, which has been reactivated. Burke (1971) associated the seismic activity of Ghana with the junction of the chain fracture zone and the African continental margin. 
Blundell and Banson (1975), Blundell (1976), suggested that continuous strike slip movement on the Romanche fracture zone adjacent to the West African continental margin may be the cause of the earthquakes. Ambraseys and Adams (1986) studied the history of earthquakes in West Africa and were of the view that Accra, the capital of Ghana is the most seismically active area in the region.

A recent review of geological and instrumental recordings by Amponsah (2002) shows that earthquakes have occurred in the past and are still liable to occur within the vicinity of the intersection of the Akwapim fault zone and the Coastal boundary fault.

Microseismic studies in southern Ghana indicated that the seismicity is associated with active faulting (Essel, 1997) between the eastwest trending Coastal boundary fault and a northeast-southwest trending Akwapim fault zone, defined by a number of active faults. A geophysical study by Essel indicated that the seismic activity is related to deep-seated faults.

\section{Earthquakes in Ghana}

Junner (1941) gave a report on historical earthquakes in Ghana. Ambraseys and Adams (1986) studied the seismicity of West Africa, which included the history of earthquakes in Ghana. Their findings on the history of earthquakes in Ghana are presented in the paper.

The first earthquake in Ghana according to Ambraseys and Adams occurred in 1615. The fortress of Sao Jorge at Elmina was destroyed. This was followed by a few aftershocks a couple of months later. The earliest recorded earthquake in Ghana occurred at about 2:00 p.m. on 18 December 1636 in the Axim district in southwestern Ghana near the border between Ghana and the Ivory Coast. Its surface magnitude $\left(M_{s}\right)$ was 5.7 and the maximum intensity was IX on the MSK scale (Ambraseys and Adams, 1986). The buildings and underground workings of a gold mine at Aboasi, northeast of Axim collapsed burying many of the miners (Claridge, 1915). The intensities mentioned in the paper are based on the Modified Mercalli scale of India, unless otherwise stated. It ranges from I to X (Junner, 1941). There are no records of earthquakes in Ghana between 1636 and 1858 but there is the possibility that there were some minor shocks during the period. In 1858, however, an earthquake was reported to have been felt in Accra (Ambraseys and Adams, 1986).

In 1862 a very strong earthquake struck the capital city of Accra and caused considerable damage to many important structures. Its maximum intensity and magnitude $\left(M_{L}\right)$ were estimated to be IX and 6.5 respectively (Quaah, 1980). Ambraseys and Adams (1986) obtained a surface wave magnitude greater than or equal to 6.5 and a maximum intensity of IX (uncertain) on the MSK scale for this event. The castle (the seat of government) and some forts were rendered uninhabitable, together with all stone buildings (Junner, 1941). Three people were killed in Accra. The earthquake shock was felt along the coast, east of Togo and in Benin, which are neighbouring countries to Ghana. An earthquake, which was felt in Accra in 1863, appears to have been an aftershock of the 1862 earthquake but there is no detailed information on the event to confirm this. Two severe shocks rocked Accra in 1871 and 1872. The magnitudes of these events were 4.6 and 4.9 respectively and the maximum intensities were VI and VII (Ambraseys and Adams, 1986). The 1872 event caused damages to buildings in Accra. In 1883 there was another minor event, which was reported to have been felt in Accra (Junner, 1941).

Two severe shocks were felt in Eastern Ghana and Togo at about 9:00 p.m. and 9:20 p.m. on 20 November 1906. The maximum intensity of the shocks was estimated to be VIII at Ho in the Eastern region of Ghana (Junner, 1941). The magnitude $\left(M_{L}\right)$ estimation was 6.2 (Quaah, 1980), however, Ambraseys and Adams's estimation of the surface magnitude $\left(M_{s}\right)$ was 5.0 and the maximum intensity VIII on the MSK scale, which they considered uncertain. Many buildings were greatly affected by this event, some cracked and others partly destroyed. No casualties were reported for this event, also felt by people in Togo and Benin. During the same month several minor shocks were felt lasting for three weeks. 
On 11 February 1907 a fairly strong shock was felt in Accra and Lome. An earthquake located out to sea and accompanied by tidal waves destroyed the wharf at Lome in Togo on 11 May 1911. During the same day at 3:21 p.m., an earthquake was felt in Accra but did not cause any damage (Junner, 1941).

The most destructive earthquake in Ghana that caused a lot of damage and loss of life and property occurred on 22 June 1939. The earthquake occurred at about 7:20 p.m. and was felt for about 20 to 30 seconds. The earthquake was assigned a magnitude of 6.5 on the Richter scale and a maximum intensity of IX (Junner, 1941). Ambraseys and Adams (1986) estimated the surface wave and body wave magnitudes to be 6.4 and 6.8 respectively and the maximum intensity as IX (uncertain). Quaah (1980) also estimated the magnitude $\left(M_{L}\right)$ to be 6.4 . The intensity of the shock was greatest in James town, a suburb of Accra. Seventeen people were killed, 133 injured and an estimated one million pounds worth of damage done to buildings (Junner, 1941). The earthquake was extensively felt. Persons over an area of about 750000 square kilometres and at places more than 800 kilometers from Accra felt it. The epicentre was rather out to sea otherwise the felt area would have been more than the estimated figure. The earthquake was recorded teleseismically at various observatories around the world. The epicentre was located at $5.18^{\circ} \mathrm{N}, 0.13^{\circ} \mathrm{W}$ (International Seismological Summary (ISS), 1939) with a focal depth of 13 kilometres. The most prominent geological effect of the 1939 earthquake was a line of fissure in the alluvium bordering the Akwapim scarp between Weija and Fete (Junner, 1941). In April 1939 two minor shocks believed to be foreshocks of the 1939 earthquake occurred in Accra. As many as five aftershocks were felt in a day. This trend continued until July 1939.

On 11 March 1964 and 9 February 1969 earth tremors of magnitudes $\left(M_{L}\right) 4.5$ and 4.7 were recorded respectively (Quaah, 1980). Both events were felt in Accra. The 1964 event was located not far from the multi-million dollar hydroelectric dam in Akosombo.

The latest tremors, which were felt in all the regional capitals, occurred on 8 January 1997, 14 February 1997 and 6 March 1997. These events caused panic among the people in the affected areas (Amponsah, 2002). The National Earthquake Information Centre (NEIC) in the USA located the 6 March event at $5.518 \mathrm{~N}$, $0.313 \mathrm{~W}$, body magnitude $\left(M_{B}\right)$ at 4.4 and at a depth of $10 \mathrm{~km}$. The local magnitude was 4.8 on the Richter scale.

Many minor tremors were recorded from 1998 to 2002 with magnitudes ranging from 1.0 to 3.0 on the Richter scale. The intensities range from I to IV. The magnitudes of the recorded local earthquakes were obtained from a formula adopted and modified from Kanai (1983).

It is given by

$$
M_{L}=1.7 \log _{10} \Delta+\log _{10} A / T
$$

where $M_{L}$ is the local magnitude, $\Delta$ the epicentral distance in $\mathrm{km}, A=\mathrm{a} / \mathrm{m}$ the ground amplitude in $\mu, \mathrm{a}=1 / 2$ (peak to peak amplitude), $\mathrm{m}=$ magnification and $T$ is the period in seconds.

Instances where the amplitudes are clipped together, the duration method by Bacon and Banson (1980) was used.

It is given by

$$
M_{L}=2.1 \log D-1.4
$$

where $D$ is the duration time.

\section{Local seismicity}

Ghana has been struck by damaging earthquakes in the past, and is currently experiencing minor tremors regularly, as indicated by current instrumental records. The latest tremors that occurred on the 14 February and 6 March 1997 and most of the recent microseismic activities were very threatening registering more than 4.0 on the Richter scale. Accra, the capital city, with a growing number of large industrial activities is located in the earthquake-prone zone.

Microseismic studies in the country indicate that the seismic activity is associated with active faulting, particularly near the intersection of the two major fault zones, the Coastal boundary fault and Akwapim fault zone. Most of the located earthquakes have their epicen- 
tres near the junction of these faults (fig. 1). The epicentres are related to the level of activity of these faults. Therefore it is not recommended that any infrastructure be located near them.

An awareness programme on earthquakes was began four years ago to sensitise the public about the dangers of earthquakes and what they have to do before, during and after an earthquake. They are also advised to retrofit already built structures and to adhere to building regulations of the country.

\section{Conclusions}

This paper has presented the main trends of seismic activity in Ghana. The capital city Accra has been struck by damaging earthquakes as well as many minor tremors from time to time. Instrumental recordings of earthquakes have indicated continuous microseismic activity in southeastern Ghana. With the current local events registering more than 4.0 on the Richter scale, the Geological survey department has embarked on an intensive education on earthquakes to the general public and schools. The outcome of the educational programme is very encouraging. Apart from this, engineering infrastructures are being designed to meet the requisite standards and also are properly located to avoid any catastrophe in the near future, if a major earthquake should strike the country.

\section{Acknowledgements}

I am grateful to Mr. S.K. Amponsah and Prof. R.K. Nkum for their comments and help. My indebtedness to the Abdus Salam Interna- tional Center for Theoretical Physics and the Swedish International Development Agency for sponsoring my stay in Trieste and making available to me all their facilities.

\section{REFERENCES}

Ambraseys, N.N. and R.D. AdAms (1986): Seismicity of West Africa, Ann. Geophysicae, 4B (6), 679-702.

Amponsah, P.E. (2002): Seismic activity in relation to fault systems in Southern Ghana, J. African Earth Sci., 35, 227-234.

BACON, B. and A.O. QUAAH (1981): Earthquake activity in Southeastern Ghana 1977-1980, Bull. Seismol. Soc. Am., 71, 771-784.

BANSON, J.K.A. (1970): Methods of studying seismicity at short range, M.Sc. Thesis (University of Edinburgh), 5-98.

Blundell, D.J. (1976): Active faults in West Africa, Earthquakes Planet Sci. Lett., 31, 287-290.

BLundelL, D.J. and J.K.A. BANSON (1975): Interpretation of a seismic Reflection survey across the Continental shelf South of Accra and it's bearing on Earthquakes in the Area, Ghana Geol. Surv. Rep. No. 75/1, pp. 7.

BURKE K. (1969): The Akwapim fault, a recent fault in Ghana and related faults of the Guinea Coast, J. Min. Geol., Nigeria, 4, 29-38.

Burke, K. (1971): Recent faulting near the Volta dam, Nature, 231, 439-440.

Claridge, W.W. (1915): A History of Gold Coast and Ashanti (London), 4-90.

EssEL, P.E. (1997): Geophysical Investigation of the Seismicity of the Weija Area, M.Phil. Thesis (University of Ghana, Legon), 61-63.

INTERNATIONAL SEISMOLOGICAL SUMMARY (ISS) (1939): Annual Bulletin, Kew Observatory, Richmond.

JunNer, N.R. (1941): The Accra Earthquake of June 1939, Gold Coast Geol. Surv. Bull., 13, 3-41.

KanaI, K. (1983): Engineering Seismology (University of Japan, Tokyo).

Leube,A., W.Hirdes, R.Mauer and G.O Kesse (1990): The early Protorezoic Birimian Supergroup of Ghana and some aspects of its associated gold mineralization, Precambrian Res., 46, 139-165.

QuAAH, A.O. (1980): Microseismicity, past seismic Activity and seismic Risk in Southern Ghana, Ph.D. Thesis (University of London), 10-223. 